\title{
KINERJA LEMBAGA PERWAKILAN RAKYAT DAERAH (Studi Deskriptif Kualitatif Di DPRD Kota Bengkulu)
}

\author{
OLEH : \\ HARIUS EKO SAPUTRA \\ Dosen Prodi Administrasi Publik Fakultas Ilmu Sosial UNIVED Bengkulu
}

\begin{abstract}
Almost every day, in various mass media, especially in newspapers, it is found that there are so many complaints and unsatisfactory opinions from the community, as the customer, towards the current implementation of public service. These complaints and unsatisfactory opinions can describe how bad the quality of the current public service is, which is benefited by the community. It may be the right time for the community to be treated as citizens, who will have rights and give priority to their rights for being served afterwards. They are not anymore being considered as clients who previously have no any choice in choosing and in determining what kind of service that they really want to. There are so many results from research, seminar and writings that are conducted by experts in which their works talk about the implementation of a good and qualified public service. Currently, however, the qualified public service has not yet implemented as should have been. The implementation of public service still acts as however it please to be and only emphasize on its own interest without considering the consumer's importance as the party that should really be served as well as possible. For this reason, a research, which is done in Service Integrated Unit of the Jember Regency, tries to find out any factors affecting quality of the public services. The main core of the public service implementation is the quality of norm of the service executor. The matter that should be realized is that the executor is the person who should serve for the community, and the community is the one who should be served as well as possible.
\end{abstract}

Keywords: Implementation of public service, legislatif

\section{PENDAHULUAN}

Lembaga perwakilan rakyat daerah dan juga merupakan unsur dari pemerintahan daerah, Dewan Perwakilan Rakyat Daerah (DPRD) mempunyai peran yang sangat strategis dalam mewarnai jalannya pemerintahan demokratis di daerah. Sebagaimana dinyatakan dalam
Ketentuan Umum Pasal 1 ayat 4 Undang-Undang Nomor 32 yang berbunyi : "Dewan Perwakilan Rakyat Daerah yang selanjutnya disebut DPRD adalah Lembaga Perwakilan Rakyat Daerah sebagai unsur Penyelenggara Pemerintah Daerah".

Beberapa isu kritis yang mesti dicermati pada saat diberlakukannya 
Undang-Undang Nomor 32 Tahun 2004 (sebagai hasil revisi dari Undang-Undang Nomor 22 Tahun 1999): Pertama, kedudukan Dewan Perwakilan Rakyat Daerah (DPRD) dalam sistem desentralisasi dan demokrasi. Kedua, ruang lingkup kewenangan, tugas pokok, dan fungsi serta hak-hak Dewan Perwakilan Rakyat Daerah (DPRD). Ketiga, kapasitas dan performance Dewan Perwakilan Rakyat daerah (DPRD) dalam menjalankan kewenangan dan fungsinya itu. Ketiga isu di atas sangat berkaitan dan disebutkan sebagai sumber dari problematika Dewan Perwakilan Rakyat daerah (DPRD) dalam tata demokrasi baru (PLOD : 2006, KPB : 2006).

Ketiga isu diatas sangatlah urgen dikarenakan fenomena yang terjadi pada tataran kekinian, banyaknya praktek buruk yang dilakukan oleh Dewan Perwakilan Rakyat Daerah (DPRD) baik itu dilakukan oleh individual maupun secara kelembagaan dari semenjak reformasi (diberlakukannya UndanUndang Nomor 22 Tahun 1999) sampai dengan sekarang (diberlakukannya Undang-Undang 32 Tahun 2004) Merupakan potret buram demokrasi di tanah air.

Praktek buruk yang sering dipertontonkan oleh DPRD diantaranya adalah komoditifikasi Peraturan Daerah (PERDA), pengawasan yang kebablasan. Dalam hujan kritikan tersebut, kita menyaksikan bahwa Dewan Perwakilan Rakyat Daerah (DPRD) dibiarkan sendirian dalam mencoba menjawab tantangan tersebut. Konsekuensinya, beberapa Dewan perwakilan Rakyat daerah (DPRD) sanggup menerima tantangan dan lahir sebagai dewan yang di hormati dan dipercaya, namum banyak yang terperangkap dalam budaya-budaya warisan lama tanpa tahu bagaimana membebaskan diri.

Berdasarkan uraian dari latar belakang di atas, maka masalah yang akan dijawab pada penelitian ini adalah Bagaimana kinerja Dewan Perwakilan Rakyat Kota Bengkulu Periode 2004-2009. Adapun tujuan dalam penelitian ini adalah untuk mendeskripsikan kinerja DPRD Kota Bengkulu dalam melaksanakan fungsi penganggaran (budgeting), fungsi legislasi, fungsi pengawasan (controlling).

\section{METODE PENELITIAN}

Bogdan dan Taylor (1975) menyatakan, penelitian deskriftif yaitu upaya untuk menggambarkan secara tepat mengenai sifat-sifat individu, keadaan, gejala dan kelompok tertentu, menentukan frekuensi adanya hubungan tertentu dalam masyarakat. Sedangkan penelitian kualitatif merujuk kepada prosedur penelitian yang menghasilkan data deskriftif, yakni apa yang dituturkan orang, baik lisan maupun tulisan, apa yang dilakukan orang, yang secara fundamental bergantung pada pengamatan manusia dalam kawasan sendiri dan berhubungan dengan orang tersebut dalam bahasannya serta dalam peristilahannya. Adapun teknik pengumpulan data yang digunakan dalam penelitian ini adalah observasi, wawancara mendalam dan dokumentasi. 


\section{HASIL PENELITIAN DAN PEMBAHASAN}

\section{Fungsi Penganggaran}

Paradigma baru dalam pengelolaan anggaran adalah dengan diberlakukannya anggaran yang berbasiskan kinerja (performance budgeting), diharapkan dengan paradigma baru ini masyarakat lebih menyadari hak publiknya dalam anggaran daerah dan menuntut agar anggaran berpihak kepada kepentingan rakyat, dikelola secara transparan dan wajib dipertanggungjawabkan di depan masyarakat. Hal ini harus didasarkan pada prinsip akuntabilitas dengan menjalankan prinsipvalue for money (ekonomis, efisien dan efektif) dengan kinerja yang terukur.

Ada beberapa aspek penting dalam anggaran kinerja adalah sebagai berikut :

1. Aspek legal, bahwa setiap transaksi yang dilakukan harus dapat dilacak otoritas legalnya sehingga jelas kemana meminta pertanggung jawabannya.

2. Aspek pengelolaan dan pertanggung jawaban, bahwa anggaran melindungi dan meningkatkan asset fisik dan non fisik daerah serta mencegah terjadinya pemborosan dan salah arus.

3. Aspek pengeluaran daerah, setiap pengeluaran harus berorientasi pada pencapaian visi, misi, tujuan, sasaran dan hasil (manfaat) yang akan dicapai.

\section{Fungsi Pengawasan}

Fungsi pengawasan DPRD pada dasarnya adalah sebuah proses berkelanjutan, sistematis dan mengacu kepada tahapan-tahapan yang relatif baku. Dalam konteks lembaga poitik, fungsi pengawasan yang dijalankan oleh DPRD merupakan bentuk pengawasan politik yang bersifat strategis dan bukan administratif. Hal ini yang membedakan fungsi pengawasan yang dilakukan DPRD dengan fungsi pengawasan yang dilakukan oleh lembaga pemerintahan dan publik lainnya. Fungsi pengawasan DPRD lebih bersifat politis strategis menyangkut pencapaian tujuan pemerintahan dan pembangunan daerah secara umum. Ia bukanlah pengawasan yang bersifat teknis administratif yang berkaitan dengan pelaksanaan administrasi pemerintahan dan pembangunan daerah.

Seperti halnya fungsi pengawasan pada umumnya, fungsi pengawasan DPRD berdasar pada rencana yang dilengkapi dengan standar atau ukuran yang jelas untuk menentukan sebuah kegiatan lembaga atau kebijakan publik dikatakan "berhasil", "gagal", atau "menyimpang" dalam pelaksanaan rencana tersebut. Maka, dapatlah dikatakan pengawasan DPRD tidak sekedar bersifat observatif, melainkan juga korektif untuk menjamin pencapaian tujuan. Hal demikian seperti yang sudah dijelaskan di atas belum dapat direalisasikan di DPRD Kota Bengkulu.

\section{PENUTUP}

\section{Kesimpulan}

Seperti sudah disampaikan sebelumnya, secara normatif, DPRD 
mempunyai tiga fungsi : fungsi legislasi, anggaran, dan fungsi pengawasan. Kegiatan ketiga fungsi ini merupakan alat untuk menjalankan fungsi utama DPRD yaitu keterwakilan (representativeness). Secara operasional, ketiga fungsi tersebut berjalan seiring dan saling melengkapi. Sebagai contoh, di dalam menjalankan tugas pengawasan bentuk atau model pengawasan yang dapat dilakukan adalah dengan mengajukan dan menyetujui peraturan daerah mengenai isu tertentu sehingga pemerintah daerah harus menjalankan kebijakan berdasarkan perda yang sudah disetujui oleh DPRD. Pengawasan dengan cara melahirkan perda ini sering disebut pengawasan melalui pembentukan perda. Contoh lain dalam optimalisasi fungsi pengawasan adalah dengan memperkuat fungsi anggaran.

\section{Saran}

Pada pelaksanaan fungsi legislasi, perlu adanya penguatan pada kapasitas pada fungsi legislasi karena kalau kita melihat hasil penelitian, masih lemahnya kinerja DPRD Kota Bengkulu dalam menjalankan fungsi legislasi ini. Satu periode jabatan ( lima tahun) hanya menghasilkan 33 (tiga puluh tiga) buah perda dan masih menyisakan 15 (lima belas) buah perda yang masih tak terselesaikan. Penguatan kapasitas DPRD ini dilakukan dengan mengikuti pelatihanpelatihan dan orientasi-orientasi di bidang draft legal sehingga di dapat sebuah pemahaman yang utuh tentang penyusunan sebuah perda sehingga perda yang dihasilkan bisa efektif dan berdaya guna. Juga perlu adanya kontrol bagi individuindividu DPRD yang "malas" dalam pembahasan-pembahasan sebuah perda dengan memberikan sanksisanksi apabila individu-individu tersebut tidak menjalankan fungsinya dengan baik.

\section{DAFTAR PUSTAKA}

Bernardi. H John \& Joyce Russel, 1993. Human Resource management Inc Singapura Mc, Grow-Hill.

Bogdan, Robert dan Steven J Taylor. 1993. Kualitatif Dasar-Dasar Penelitian. Indonesia, Surabaya

Dwiyanto, Agus. 1999. Penilaian Kinerja Organisasi Pelayanan Publik; Makalah Seminar Kinerja Organisasi Sektor Publik Kebijakan dan Persiapannya Yogyakarta, Jurusan Administrasi Negara, Fisipol UGM

Djojosoekarto, Agung, dan Nugroho, Riant, dan Djayasinga, Marselina. 2004. Membangun Kapasitas Fungsi Penganggaran DPRD. Jakarta, Saint Communication

Djojosoekarto, Agung, dan Nugroho, Riant. 2004. Akuntabiltas Publik dan Fungsi Pengawasan DPRD Jakarta, Saint Communication 
Gaffar, Afan. 2000. Politik Indonesia; Transisi Menuju Demokrasi Yogyakarta, Pustaka Pelajar

Imawan, Riswandha. 2000. Agenda Politik dan Ekonomi Dalam Format Reformasi Menuju terbentuknya Masyarkat Madani Dalam Membongkar Mitos Masyarakat Madani. Yogyakarta, Pustaka Pelajar

Imawan Riswandha. 2001. Fungsi Perwakilan; Pembentukan Legitimasi dan Pengambilan Keputusan, Handout Mata Kuliah Sistem Politik dan Pemerintahan $R I$. UGM, MAP

Kaho, Josef. 1991. Prospek Otonomi Daerah (Identifikasi Beberapa Faktor Yang Mempengaruhi penyelenggaraan). Jakarta, CV Rajawali

Keban, Yeremias T. 1995. Indikator Kinerja Pemerintah Daerah; Pendekatan Manajemen dan Kebijakan, Seminar Sehari Kinerja Organisasi Sekitar Sektor Publik Kebijakan dan Penerapan, Yogyakarta, PMAP, UGM.

Moleong, Lexy J. 2001. Metodologi Penelitian Kualitatif. Bandung, PT Remaja Rosdakarya
Nawawi, Hadari. 1998. Metodologi Penelitian Bidang Sosial. Yogyakarta, Gadjah Mada University Press

Poerwadarminta, WJS.1991. Kamus Bahasa Indonesia. Jakarta, Balai Pustaka

Sanit, Arbi. 1995. Perwakilan Politik Indonesia. Jakarta, CV Rajawali

Singarimbun, Masri dan Sofyan, Effendi. 1989. Metodologi Penelitian Survey. Jakarta, LP3S

Thoha, Miftah, 1989, Pembinaan Organisasi; Proses Diagnosa dan Intervensi. Jakarta, Rajawali,

Tangkilisan, Hessel. 2003. Manajemen Modern Untuk Sektor Publik. Yogyakarta, Balairung

Wibawa, Samudra. 1994. Kebijakan Publik; Proses dan Analisis, Jakarta, Intermedia

Yunita, Rahmi. 2004. Menjadi Wakil Rakyat Dalam Tata Demokrasi Baru. Jakarta, Saint Communication

Zauhar, Soesilo. 1996. Reformasi Administrasi; Konsep, Dimensi, dan Srategi. Jakarta, Bumi Aksara

Undang-Undang Republik Indonesia Nomor 32 Tahun 2004 Tentang Pemerintahan Daerah. 
Peraturan Menteri Dalam Negeri Nomo 59 Tahun 2007 Tentang Perubahan Atas Peraturan Menteri Dalam Negeri Nomor 13 Tahun 2006 Tentang Pedoman Pengelolaan Keuangan Daerah.

Keputusan Kepala LAN RI Nomor 589/IX/1999 Tentang Pedoman Penyusunan Laporan Akuntabillitas Kinerjja Instansi Pemerintah.
Tata Tertib Dewan perwakilan Rakyat Daerah Kota Bengkulu Tentang Perubahan Tata Tertib Dewan Perwakilan Rakyat daerah Kota Bengkulu 